\title{
CONVERSATION ANALYSIS: TURN-TAKING MECHANISM AND POWER RELATION IN CLASSROOM SETTING
}

\author{
${ }^{1}$ Candrika Citra Sari* \\ ${ }^{1}$ Universitas Bina Nusantara, Indonesia \\ *Corresponding Author: candrika.sari@binus.ac.id
}

\begin{abstract}
Institutional conversation in the classroom has been known to be fully controlled by the teacher in order to achieve specific goals of the teaching and learning process. This study aims at finding out how teachers manage the flow of classroom interaction, how students may possibly take the floor and issue about power and hierarchy between teacher-students in a teacher-fronted whole classroom interaction. The result is expected to give an overview or a reflection on how teachers encourage learning to happen by the way they use their power to manage the turn taking mechanism in a whole class interaction. The data is in the form of unscripted classroom interaction in the field of language from YouTube. Specifically, the analysis is focussed on analysing the turn-taking rules in a whole class interaction using Conversation Analysis (CA). Gesture is also one means of communication which accompanied verbal communication, and therefore to enrich the data, gestures of the participants are also taken into consideration. This study found that teacher and students turn is asymmetrical. However, teacher possesses no absolute power in term of controlling the turn-taking as students appeared to overlap the teacher's talk to take the turn and try to perform unfocalized effort to nominate themselves as the first speaker using gestures. The content of teachers' TCU indicates that the teacher tries to stimulate the students' critical thinking by posting open-ended question, and evaluates and responds students' answers by using follow-up question.
\end{abstract}

Keywords: Classroom Interaction; Conversation Analysis; Power Relation; Turn Taking

\begin{abstract}
ABSTRAK
Untuk mencapai tujuan pembelajaran, secara umum diketahui bahwa percakapan di ruang kelas dikontrol oleh guru. Penelitian ini menginvestigasi bagaimana guru mengontrol jalannya percakapan dalam diskusi kelas dan bagaimana siswa dimungkinkan untuk mendapatkan giliran dalam berbicara. Selain itu, power dan hirarki dalam interaksi di kelas juga menjadi poin lain yang menjadi fokus dalam penelitian ini. Penelitian ini menyuguhkan hasil penelitian yang didapat melalui metode analisis percakapan (Conversation Analysis). Hasil penelitian ini diharapkan dapat menjadi gambaran atau sarana refleksi tentang bagaiama guru mengatur mekanisme percakapan dalam kelas besar. Data dalam penelitian ini adalah sebuah video interaksi kelas yang diupload ke YouTube. Secara spesifik analisis akan meliputi turn-taking rules (mekanisme giliran berbicara) dan juga gerak tubuh yang terlibat untuk mengalokasikan dan mengambil giliran dalam berbicara. Penelitian ini menemukan bahwa interaksi guru dan siswa di kelas tidak simetris. Meskipun demikian, guru dalam penelitian ini tidak memiliki power yang absolut dalam mengontrol interaksi karena terdapat bukti dimana siswa memotong pembicaraan guru. Selain itu, siswa juga secara terbuka menunjukkan keinginannya untuk mengambil alih giliran berbicara dengan cara mengangkat tangan mereka. Isi dari TCU guru mengindikasikan bahwa guru mencoba untuk menstimulasi siswa dalam berpikir kritis dengan memberikan pertanyaan-pertanyaan terbuka dan menindaklanjuti pertanyaan tersebut berdasarkan respon atau jawaban yang diberikan oleh siswa.
\end{abstract}


Celtic: A Journal of Culture, English Language Teaching, Literature and Linguistics

Vol. 7, No. 2, December 2020.

E-ISSN: 2621-9158 P-ISSN:2356-0401

http://ejournal.umm.ac.id/index.php/celtic/index

Kata Kunci: Analisis Percakapan; Giliran Berbicara; Hubungan Kekuasaan; Percakapan Di Ruang Kelas

\section{INTRODUCTION}

Talking is an activity which is typically done by more than one participant who normally performs turn-taking during the talk (Cameron, 2001). In an effective conversation, overwhelmingly one party talks at a time and speaker-change does occur accordingly (Okata, 2016; Sacks et al., 1978). This gives an idea that turn-taking organization among participants is fundamental in conversation. In conversation analysis (CA) which is coined by (Sacks et al., 1978) Transition Relevance Place (TRP) and Turn Constructional Unit (TCU) are the important parts of turn-taking organization analysis. Turns are constructed through not less than one or more than one TCUs. The end of TCU is very important because it may possibly be TRP which simply means that speaker change may occur (Cameron, 2001). Participants employ different kinds of ways to project the end of the current speaker's turns (TRP). TCU which is ended with TRP is usually complete in term of semantics, grammar, and intonation (Cameron, 2001; Sahlström, 2002). In addition, aspects of nonverbal behaviours, such as gazing to the selected participant at the end of the TCU can also be seen as a turn yielding signal (Cameron, 2001; Rossano et al., 2009) or pointing to the nominated participant (Kääntä, 2012; Mondada, 2013). In a natural conversation, turn allocation technique can be divided into two; the first turn is nominated by the current speaker and the next turn is allocated by self-selection (Sacks et al., 1978). This means if the next speaker is already chosen by the current speaker, he/she has to speak and other participants have no right to take the turn. Meanwhile, participants can self-select themselves if the next speaker has not been chosen by the current speaker. When no one is nominated by the current speaker and no one want to self-select him/herself, then current speaker can keep the turn (Ingram \& Elliott, 2014).

Different from the natural conversation of which the participants' right to construct turn are mostly symmetric, turn allocation in institutional setting, such as in a classroom, especially during a lesson, is driven by the teacher. During a lesson, the teacher will be the one who decides about who can talk, when to talk, and what to talk and so the interaction's relationship is seen as asymmetrical (Garton, 2012). A number of Conversation Analysis (CA) study have been conducted in classroom setting (i.e. Evnitskaya \& Berger, 2017; Garton, 2012; Mchoul, 1978; Seedhouse, 2004). One of the early and influential study done on the basis of CA was from Mchoul (1978). Based on the result of his study of the structure of turn-taking in Geography class, Mchoul (1978) developed sets of turn-taking structure between teacher and students during a lesson. According to Mchoul's (1978) rule, if the teacher acts as the current speaker, the teacher can select the next speaker. The selected student must take the turn and other students do not have the right to speak. Yet, if the teacher has not yielded the floor to the students, the teacher has to continue the turn. Students can self-select themselves, but they will need to get approval from the teacher to speak. In other words, the teacher retains his/her right as the first speaker in a whole classroom interaction. From McHoul's rules it is important for the teacher as the first speaker to be able to manage the turn taking very well as Gardner (2019) points out that one necessary condition for learning to happen is setting up participation interaction to allow joint attention. 
Sari, C.C. (2020). Conversation Analysis: Turn-Taking Mechanism and Power Relation in Classroom Setting. Celtic: A Journal of Culture, English Language Teaching, Literature, \& Linguistics, 7(2), 118-136.

Research also found that opportunities to participate actively in lesson is advantageous in learning (Allwright, 2005; Walsh, 2011). For this reason, as the first speaker, teachers need to trigger the students to participate and engage in a whole class interaction by distributing the turn equally.

Nonverbal resources to manage turn allocation in classroom setting has also gain attention (Kääntä, 2012; Sahlström, 2002; Waring, 2014). In order to allocate turns to the students, Kääntä (2012) finds that teachers employ embodied actions, such as gazing, nodding head and performing hand gestures simultaneously with talk in whole class instructional interaction. Even though it is known that interaction in a classroom setting is asymmetrical (Brooks, 2016; Evnitskaya \& Berger, 2017; Seedhouse, 2004), research has shown that students might also nominate themselves to take the turn (Kääntä, 2012; Sahlström, 2002; Waring, 2014). In multiparty institutional setting such as classroom, various multimodal actions might involve to enrich the interaction. It is undeniable that hand raising is a quite observable movement to indicate the students' willingness to take the turn. Sahlström (2002) conducted a research about hand-raising in classroom interaction and found that in general, students raise their hands at the teacher's turn or at the end of the teacher's TCU which is accurately projected as TRP to indicate their willingness to take the turn without disturbing the teacher's turn. However, Sahström (2002) underlines that the teacher's TCUs tend to be shorter when the students raise their hands while the teacher is speaking. These studies imply that students do influence teachers' next speaker selection. However, apparently teacher is not always yield the floor to the students who raised their hands as in Waring (2014) study, it is found that teachers sometimes "bypass" students' non-verbal bid such as hand raising to involve non-bidding students.

Apart from being responsible to manage the turn allocation, teachers' power may also visible through the structure of classroom talk between teacher and student. Brooks (2016) found an evidence that in a face to face classroom interaction, teacher maintains certain power structures over class discussion. She found evidence that teacher acts as "Questioner" who continuously throws questions and evaluates students' response. This finding correlates to Mehan (1979) in Brooks, (2016) teacher-students classroom interaction patterns: IRE (Initiation, Response, Evaluation) or IRF (Initiation, Response, Feedback) pattern. Not only shown by spoken discourse, teacher's power is also embodied in the spatial arrangement of a classroom in which the teacher has the absolute right to stand and move around the classroom while others can only do that when they are told by the teacher also reflect that the teacher has greater participation's right than the students (Mchoul, 1978).

Even though previous researches have examined teacher-students interaction during teacher-fronted classroom time, none of it discussed about the turn taking mechanism of the interaction in detailed, covering the approximate length or the characteristics of the teacher and students TCU, either when they took turn after being appointed or when they overlapped each other speech. In addition, this study also interested in examining the power and hierarchy in classroom interaction through the turn taking mechanism and the content of teacher's TCU and students' TCU. This becomes important to give overview or reflection on how should teachers encourage learning to happen by the way they utilize their power to manage the turn taking mechanism in a whole class interaction. In short, I seek to answer these following 
Celtic: A Journal of Culture, English Language Teaching, Literature and Linguistics

Vol. 7, No. 2, December 2020.

E-ISSN: 2621-9158 P-ISSN:2356-0401

http://ejournal.umm.ac.id/index.php/celtic/index

research questions.

1. What is the turn-taking patterns of the teacher-students interaction during teacherfronted classroom time under investigation of this study; including how the teacher signals the turn allocation and how the students indicate their intention to take the turn, and the length of the students TCU when they take turn after/without being nominated?

2. How power and hierarchy are being represented in the teacher-fronted classroom interaction under investigation of this study as representing by the content of teacher's TCU and students' TCU?

\section{METHOD}

The data used for this study is unscripted classroom interaction video recording which was uploaded by Wakefield (2010) on YouTube at the following URL https://www.youtube.com/watch? $\mathrm{v}=\mathrm{tAz} 7 \mathrm{TD} 02 \mathrm{ytU}$. The total duration of the video is 9.59 , but only approximately the first 6 minutes of the video was transcribed. The stretch of interaction under study begins at 0.01 and ends at 6.17. In this video, there was one female teacher engaged in a whole class interaction with approximately 17 students. Due to privacy reason, all identified names mentioned in the video were converted into pseudonym. From the video, the teacher circulated around the classroom while delivering teachers talk, whereas, the students sat on their seats. They learned and discussed about the meaning of some words and the root of words which were related to a language class genre.

The YouTube video was converted to a WAV file and exported to ELAN; a computer software to transcribe and annotate audio recording (ELAN (Version 4.9.4), 2016). The teacher's hand gestures when allocating the turn, such as pointing hand, and also the students' gesture, such as hand-raising are recorded in the transcription. Following Kääntä (2012), in the transcription, the gestures were written in between wavy brackets $(\{\ldots\})$. Additionally, in an attempt to indicate the time when the hand gestures were performed, the explanation of the gesture was written underneath the stretch of speech which was produced at the same time as the occurrence of the hand gesture (see Appendix 1 for the complete key of the transcription convention).

CA (Conversation Analysis) coined by (Sacks et al., 1978) is applied in order to find the turn-taking's rule of the data under investigation. The Turn Constructional Unit (TCU) and the Transition Relevance Place (TRP) are analysed based on CA theory by focussing on the speaker's intonation (raising or falling), how the speakers yielded the floor to other speakers, how the speakers nominated themselves to take the turn, the content of the speakers' TCU and also the words that the speakers used to manage the turn allocation. All of these aspects were recorded in a detailed transcription (see Appendix 2 for the full transcription). In addition to the verbal cues performed by the speakers, the physical turn-taking regulating signals such as hand raising performed by the participants were also examined to reveal the teacher's way in allocating the turn and the student's strategies to perform turn-taking initiation. 
Sari, C.C. (2020). Conversation Analysis: Turn-Taking Mechanism and Power Relation in Classroom Setting. Celtic: A Journal of Culture, English Language Teaching, Literature, \& Linguistics, 7(2), 118-136.

\section{FINDINGS}

\section{Turn-Taking Pattern}

Six extracts along with the explanation are presented to reveal the general turntaking rule of the investigated classroom interaction. Extract 1 and 2 are the examples of the most occurring turn-taking patterns. Extract 3, 4, 5, and 6 are the examples of the less occurring turn-taking patterns. From the presented Extracts, the overall rule is summarized at the end of this point.

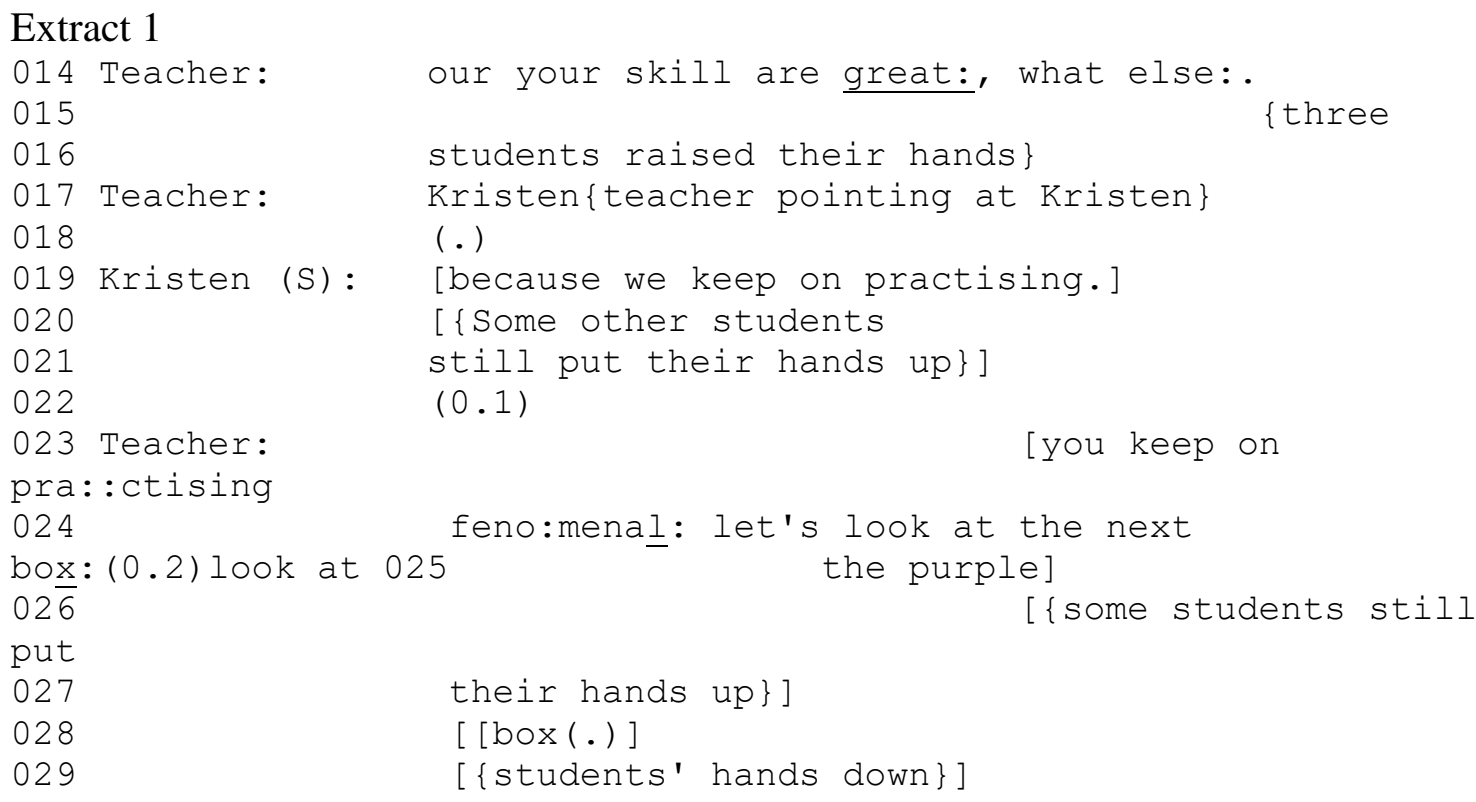

In Extract 1 (line 15), there are three students directly raising their hands at the completion of the teacher's TCU (line 14). This TRP can be accurately projected since the teacher clearly yields the floor by using the word "what" to pose a question to the students. Additionally, she lengthens the final syllable and drops the intonation a little bit at the end of her TCU (line 014). However, the students do not directly take the floor, they raise their hands until the teacher nominates the next speaker in line 017 by mentioning a student's name and pointing at the student. Then, the nominated student takes the floor by answering the teacher question. When the nominated student is speaking in line 019, the other students still indicate their intention to speak by raising their hands, but after the nominated student completed his TCU as indicated by the falling intonation, after 0.1 second gap the teacher self-selected herself to take the turn and produce stretch of speech in lines 023, 024, 025, and 028; she ignores the students' signals to take the turn until the students put their hands down in line 029. Other examples of this pattern can be found in Appendix 2, specifically, lines 050-062, lines 097-105, lines 151-168, lines 250-261.

Extract 2

215 Teacher: word]

216

217

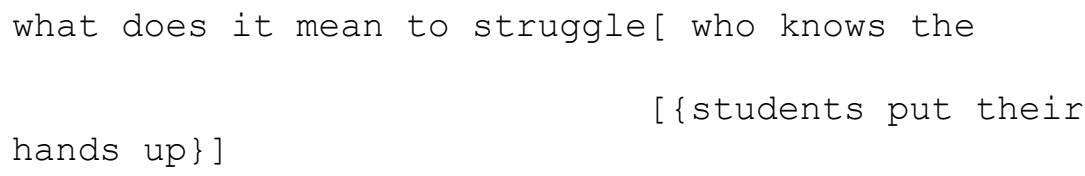


Celtic: A Journal of Culture, English Language Teaching, Literature and Linguistics Vol. 7, No. 2, December 2020.

E-ISSN: 2621-9158 P-ISSN:2356-0401

http://ejournal.umm.ac.id/index.php/celtic/index

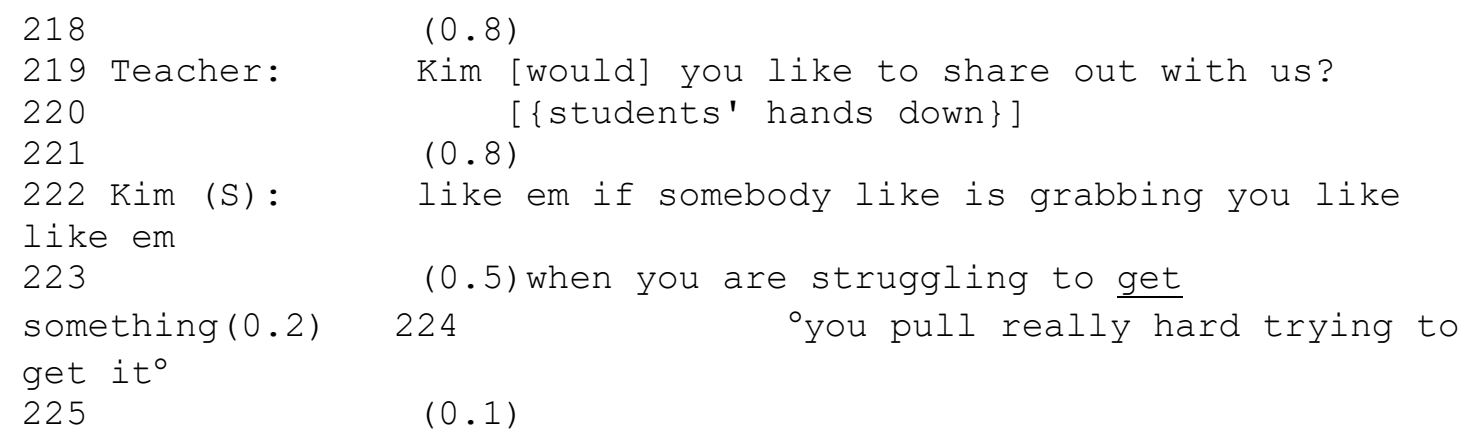

Extract 2 (line 219) shows that the teacher nominates the next speaker by only mentioning a student's name without gesture. After the next speaker is chosen, other students withdraw their hands (line 220) and the nominated student takes the turn (lines 222-225) without any interruption. Generally, during the 6 minutes whole class interaction, there is no evidence of students interrupting the nominated student's turn (see Appendix 2, specifically lines 233-242 and lines 281-290 for other examples which are the same as Extract 2).

\section{Extract 3}

083 Teacher:

when 084

085 Whole class:

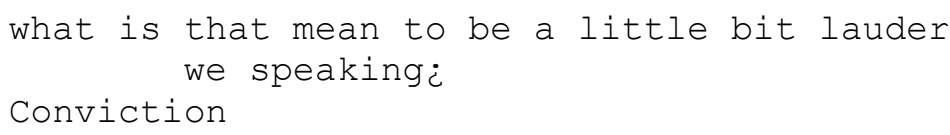

Extract 4

106 Teacher:

it's

107

108

109

up \} ]

110 Students:

111 Students:

I make something special for youx: and because

special do you think that I'm I give the same present $(0.1)$ to [everybody?

[ some students put their hands

[yes] ((calling out))

[No] ((calling out))

Extract 5

135 Teacher:

136

137

138 student 3:

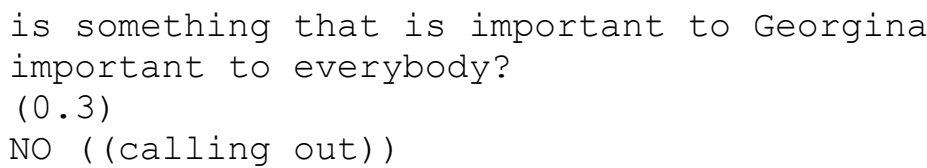

Extract 3, 4, and 5 show that in some parts of the interaction, the students do not wait until being nominated by the teacher to take the turn. In these examples, instead of raising their hands and waiting to be nominated, the students are calling out (Extract 3 line 085, Extract 4 lines 110-111, Extract 5 line 138). However, they do not overlap the teacher's speech. They call out at the end of the teacher's TCUs'. Extract 3 lines 083084, extract 4 lines 106-108 and extract 5 lines 135-136 indicate that the teachers produce grammatically and syntactically complete TCUs with rising intonation. Additionally, the teacher also clearly yielding the floor to the students by posing questions to the students by using question words; what (line 083), do (107), and is (line 
Sari, C.C. (2020). Conversation Analysis: Turn-Taking Mechanism and Power Relation in Classroom Setting. Celtic: A Journal of Culture, English Language Teaching, Literature, \& Linguistics, 7(2), 118-136.

135). It is worth noting that the students' TCUs (lines $085,110,111,138$ ) only consist of one word.

Another example of the same pattern as these three Extracts can be found in Appendix 1, lines 275-278. In other parts of the interaction, there are also evidences off some students who call out and produce TCUs' consisting of two or three words (see full transcription in Appendix 2, specifically lines 113-115 and lines 202-207).

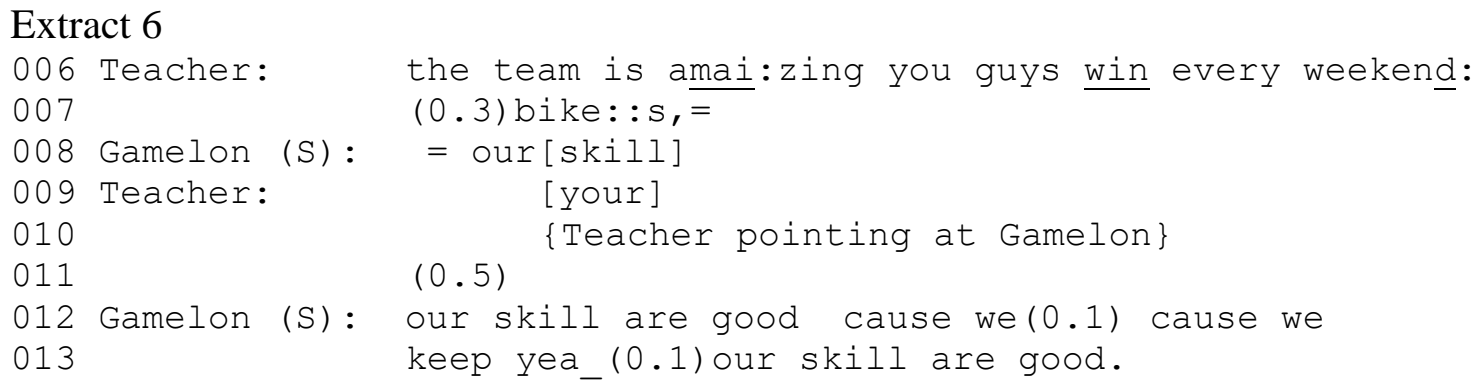

In Extract 6, Gamelon (student) self-selects himself by calling out before the teacher completely finishes her turn (line 008). Line 007 shows that the teacher's TCU is in continuing intonation. This indicates that the teacher wants to continue her turn. Besides, the overlapping speech between the teacher and Gamelon (lines 008 and 009) shows that the teacher actually has not quite finished her turn. Yet, since Gamelon has already initiated to take the turn, the teacher then finally yielding the floor and clearly nominating Gamelon as the next speaker by pointing at him (line 010). After being clearly nominated to take the floor, Gamelon produces longer TCU (lines 012-013).

Through the full transcript in Appendix 1, it is noticeable that the overlapping speeches between participants do not happen frequently. However, the participants' speeches are sometimes overlapping with the other participants' hand gestures. For instance, other students put their hands up when one student is having his/her turn (Appendix 1 lines 019-022) and students put their hands up to show their initiation to answer the teacher's question before the teacher finishes her turn (see Appendix 2 lines 014, 023-027, 050-053, 215, 069-071).

Drawing from the explanations above, the summary of the turn-taking rule is as the following.

1. The teacher clearly nominated the next speaker either by mentioning the next speaker's name or pointing at the next speaker or even both.

2. Overwhelmingly students put their hands up to indicate their initiation to take the turn and wait until being nominated.

3. When the nominated speaker is speaking, other participants do not orally interrupt.

4. Overwhelmingly one party speaks at a time; overlapping mostly occurs between the current speaker's speech and the other participants' hand gestures.

5. Students also take the turn without being nominated by the teacher, but they only produce short TCU consisting of one to three words. Mostly, they always do that at the end of the teacher's TCU when the teacher is clearly yielding the floor by posing questions.

6. There is one interactional evidence found which is deviating rule number 5; student takes the turn before the teacher completely finishes her turn. When this happened, 
Celtic: A Journal of Culture, English Language Teaching, Literature and Linguistics

Vol. 7, No. 2, December 2020.

E-ISSN: 2621-9158 P-ISSN:2356-0401

http://ejournal.umm.ac.id/index.php/celtic/index

the teacher stopped speaking and let the student took the floor.

7. The students TCUs are longer (consisting of more than 3 words in one string of TCU) when they are nominated by the teacher to take the floor.

\section{Participants' Power Relation in Classroom Interaction}

From the finding in point 4.1, the teacher power is obviously higher than the students; the teacher does not need to compete with the students to take the turn and the teacher is the one who allocates the turn. Additionally, from the data, it is evident that the content of the students' TCUs is always about answering the teacher's question which are mostly in the form of open-ended question (See Extract 7).

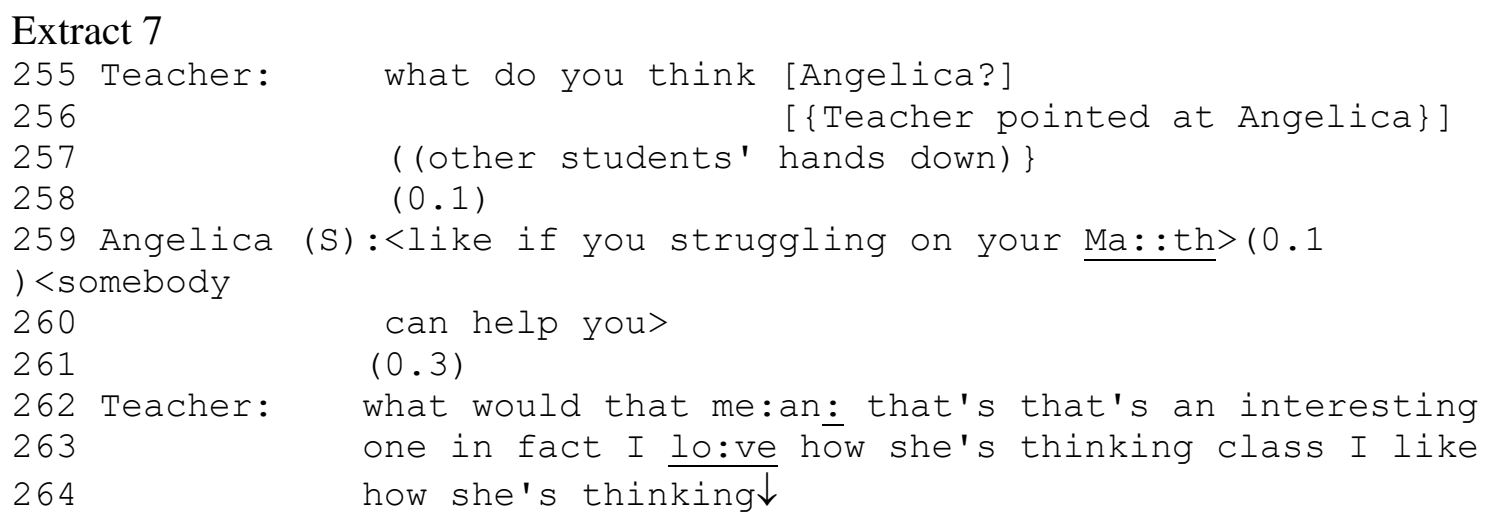

Line 255, shows that the teacher yields the floor by posing a question and directly mentioning the name of the next speaker who is responsible to take the floor. Then, the next speaker's answering the question without posing another question to the teacher (see line 259, Extract 7). After the students completed their TCUs, the teacher directly takes the turn and evaluates the student's answer by saying: "...that's an interesting one...I love how she's thinking..." (Extract 7 lines 261, 263). The teacher's evaluating the students' answer several times (see Appendix 1 line 080, lines 283-284 for other examples of teacher's evaluation). Yet, there is no evidence in the data which shows that the students also evaluating the teacher's statement. This shows that in the classroom under study, the teacher has prerogative right in the interaction to evaluate the other participants. It means the teacher has more power in the interaction.

\section{DISCUSSION}

The finding shows that the teacher appears to be the main speaker which allocate the turn and maintain the effectiveness of the teacher-students interaction. It agrees with Okata's (2016) (Sacks et al.'s (1978) findings that in a usual and effective conversation, overwhelmingly, there is only one party speaks at a time. In addition, the majority of classroom interaction in this study follows the rules of turn-taking outlined by Mchoul (1978) in which the teacher mainly acts as the main speaker who has the prerogative right to take the turn, continue the turn and/or select the next speaker, whereas the students as the teacher's interlocutors only take the turn when they are nominated. However, there are some interactional contexts where the turn taking's structure alters to that of McHoul's (1978) rule, specifically when one student self-selects himself and call out before the teacher finishes her turn, resulting in overlapping speech between them. 
Sari, C.C. (2020). Conversation Analysis: Turn-Taking Mechanism and Power Relation in Classroom Setting. Celtic: A Journal of Culture, English Language Teaching, Literature, \& Linguistics, 7(2), 118-136.

When this condition happened though, students do not produce a long string of speech, they only produce sort TCU consisting of less than three words. Yet, given that the teacher directly stopped speaking and yielded the floor to that particular student implies that student may also possess power in classroom interaction. According to Sidelinger, Bolen, Frisby, \& McMullen (2012), students may affect instructor's behaviours in classroom interaction.

The same as (Brooks, 2016), this study found that the teacher continually asks questions to the students, and then provide evaluation to the students' answer. This means, in term of the conversation content, the interactions form IRE (Initiation, Response, Evaluation) pattern of which the teacher initiates the question, the students respond to the question, and lastly the teacher evaluates the students answer. In this study, there is no evidence of students evaluate the teacher's answers, and therefore it seems that there is power difference between teacher and student. In (Brooks, 2016), the teacher only asks quiz type question of which the answer is set and known by the teacher, whereas in this study the teacher appeared to ask many open-ended questions that allow students to explore their knowledge. Then, the teacher provides constructive feedback to encourage the students elaborate their answers. This inquiry style in my opinion does not place the teacher as the "know all" and put the students as "without knowledge". This condition has lessened a social divide between teacher and students as the students gain more valued and power in class.

Besides, the data also shows that although the students are most likely wait to be nominated to speak, the fact that they still do unvocalized attempt to take the turn by raising their hands even before the teacher finishing her speech may indicate that students also have power in the interaction even though their power is not as high as the teacher. In other words, I would say that in this study the power of the teacher in managing the turn-taking mechanism is not absolute. To a certain point that students can still show their desire to be the speaker and take the turn by raising their hands and can call out their answer before being nominated.

As found in this study, teacher could mitigate the social distance between teacher and students by encouraging students to nominate themselves and exposing students with an open-ended question. By doing so students will have more freedom to talk in class and express their idea. To value the students' answer, the teacher could give feedback or develop follow up question according to the students answer, and therefore the students are forced to think critically based on the stimulation given by the teacher. By doing so, the students could be prepared to answer the $21^{\text {st }}$ century learning requirement which is explained by Ansori (2019) as having to be academically competent, critical, and able to communicate their voice.

\section{CONCLUSION}

To conclude this article, several important points are summarized in the following. The interaction between teacher and students in the data is mostly asymmetrical; the teacher acts as the first speaker who manages the turn-taking system. She nominated the next speaker by either employing hand gestures or by directly mentioning the students' name or by mentioning the student's name while also pointing at the nominated student. The teacher has higher power than the students as shown by the fact that teacher is the one who ask question and evaluate the respond. Yet, it is 
Celtic: A Journal of Culture, English Language Teaching, Literature and Linguistics

Vol. 7, No. 2, December 2020.

E-ISSN: 2621-9158 P-ISSN:2356-0401

http://ejournal.umm.ac.id/index.php/celtic/index

worth noting that in the turn-taking mechanism, the power of the teacher is not absolute as there are some evident in which the student overlapping the teacher's speech and calling out before being nominated. Besides, the fact that the students are allowed to show their eagerness to take the turn by raising their hands is also one evident that students also possess power in the interaction. This study, however, does not include the analysis of silent; pauses or gaps of the classroom interaction under investigation, whereas silent may also affect the turn-taking patterns between participants. Thus, future study can be conducted to examine pauses or gaps in classroom interaction.

\section{REFERENCES}

Allwright, D. (2005). From teaching points to learning opportunities and beyond. Tesol Quarterly, 39(1), 9-31.

Ansori, M. (2019). English teachers' efficacy in using pedagogical techniques to promote higher order thinking skills. Celtic: A Journal of Culture, English Language Teaching, Literature, and Linguistics, 6(2), 1-13.

Brooks, C. F. (2016). Role, Power, Ritual, and Resistance: A Critical Discourse Analysis of College Classroom Talk. Western Journal of Communication, 80(3), 348-369. https://doi.org/10.1080/10570314.2015.1098723

Cameron, D. (2001). Working with spoken discourse. Sage.

ELAN (version 4.9.4). (2016). Max Planck Institute for Psycholinguistics, the Language Archive. http://tla.mpi.nl/tools/tla-tools/elan/

Evnitskaya, N., \& Berger, E. (2017). Learners' Multimodal Displays of Willingness to Participate in Classroom Interaction in the L2 and CLIL Contexts. Classroom Discourse, 8(1), 71-94. https://doi.org/10.1080/19463014.2016.1272062

Gardner, R. (2019). Classroom Interaction Research: The State of the Art. Research on Language and Social Interaction, 52(3), 212-226. https://doi.org/10.1080/08351813.2019.1631037

Garton, S. (2012). Speaking out of turn? Taking the initiative in teacher-fronted classroom interaction. Classroom Discourse, 3(1), 29-45. https://doi.org/10.1080/19463014.2012.666022

Ingram, J., \& Elliott, V. (2014). Turn taking and "wait time" in classroom interactions. Journal of Pragmatics, 62, 1-12. https://doi.org/10.1016/j.pragma.2013.12.002

Kääntä, L. (2012). Teachers' embodied allocations in instructional interaction. Classroom Discourse, 3(2), 166-186. https://doi.org/10.1080/19463014.2012.716624

Mchoul, A. (1978). The organization of turns at formal talk in the classroom. Language in Society, 7(2), 183-213. https://doi.org/10.1017/S0047404500005522

Mondada, L. (2013). Embodied and spatial resources for turn-taking in institutional multi-party interactions: Participatory democracy debates. Journal of Pragmatics, 46(1), 39-68. https://doi.org/10.1016/j.pragma.2012.03.010

Okata, G. N. (2016). Turn taking sequence in discourse: A tool to effective conversation in a related speech of interlocutors. International Journal of Research in Arts and Social Sciences, 9(1), 152-161.

Rossano, F., Brown, P., \& Levinson, S. C. (2009). Gaze, questioning, and culture (J. Sidnell (Ed.); Issue Rossano 2009, pp. 187-249). Cambridge University Press. https://ebookcentral-proquest- 
Sari, C.C. (2020). Conversation Analysis: Turn-Taking Mechanism and Power Relation in Classroom Setting. Celtic: A Journal of Culture, English Language Teaching, Literature, \& Linguistics, 7(2), 118-136.

com.ezproxy2.library.usyd.edu.au/lib/usyd/detail.action?docID=461171\&pqorigsite=primo\#goto_toc

Sacks, H., Schegloff, E. A., \& Jefferson, G. (1978). A simplest systematics for the organization of turn taking for conversation. Studies in the Organization of Conversational Interaction, 7-55. https://doi.org/10.1016/b978-0-12-623550$0.50008-2$

Sahlström, F. (2002). The interactional organization of hand raising in classroom interaction. Journal of Classroom Interaction, 37(2), 47-57.

Seedhouse, P. (2004). The organization of turn taking and sequence in language classrooms. Language Learning, 54(S1), 101-140. https://doi.org/10.1111/j.14679922.2004.00270.x

Sidelinger, R. J., Bolen, D. M., Frisby, B. N., \& McMullen, A. L. (2012). Instructor compliance to student requests: An examination of student-to-student connectedness as power in the classroom. Communication Education, 61(3), 290308. https://doi.org/10.1080/03634523.2012.666557

Walsh, S. (2011). Exploring classroom discourse: Language in action. Taylor \& Francis.

Waring, H. Z. (2014). Turn allocation and context: Broadening participation in the second language classroom. In Discourse in context: Contemporary applied linguistics (Vol. 3, pp. 301-320). Bloomsbury London, England.

\section{APPENDIX 1 \\ Transcription Key}

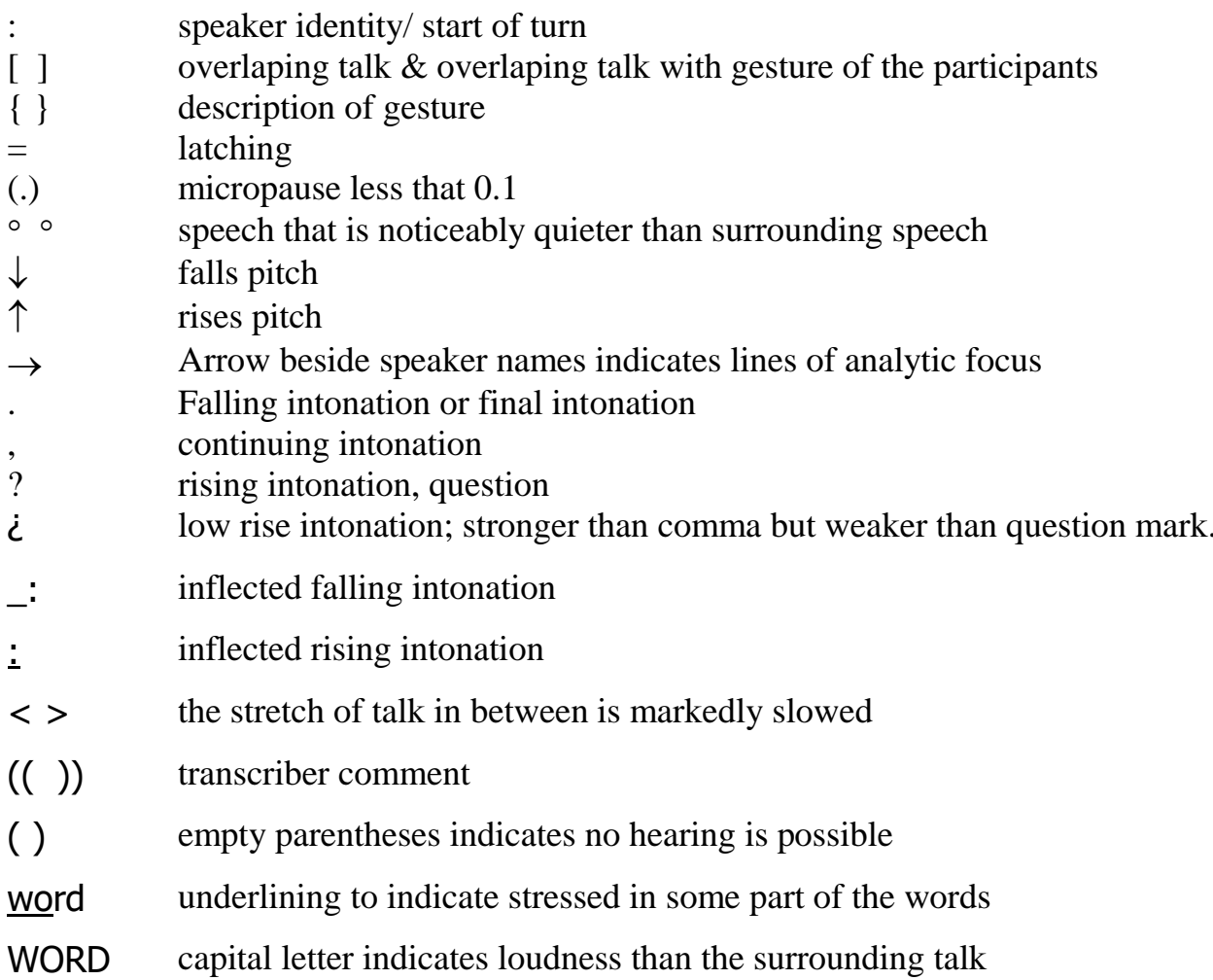


Celtic: A Journal of Culture, English Language Teaching, Literature and Linguistics Vol. 7, No. 2, December 2020.

E-ISSN: 2621-9158 P-ISSN:2356-0401 http://ejournal.umm.ac.id/index.php/celtic/index

\section{APPENDIX 2 \\ Full Transcription}

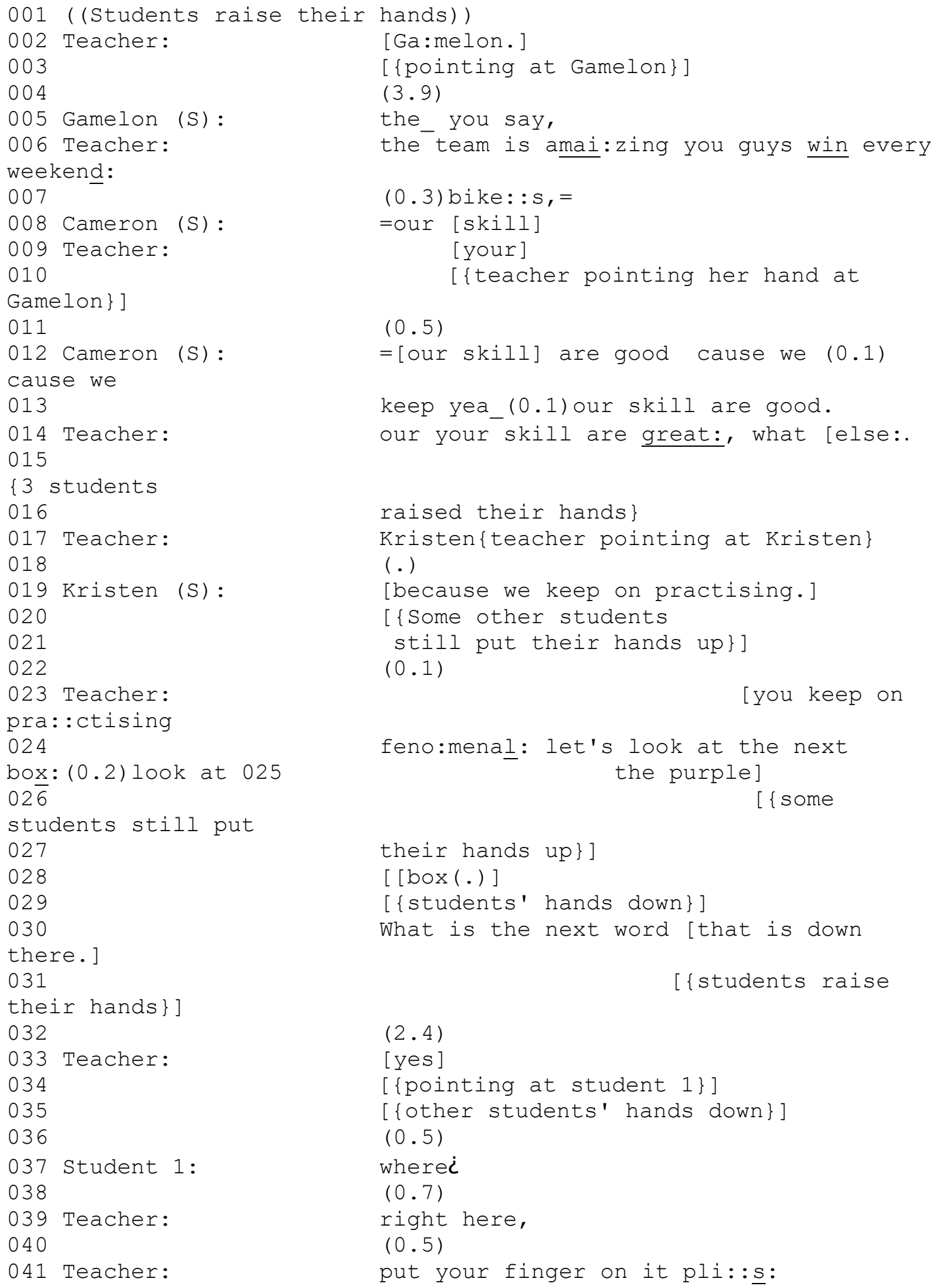


Sari, C.C. (2020). Conversation Analysis: Turn-Taking Mechanism and Power Relation in Classroom Setting. Celtic: A Journal of Culture, English Language Teaching, Literature, \& Linguistics, 7(2), 118-136.

042

043 Teacher:

044 Student 1:

spes $^{\circ}$

045 Teacher:

046 Student 1:

047

048 Teacher:

049

050 Teacher:

like what is

051

052

053

054

055 Teacher:

what is the

056

057

058

059 Teacher:

060

students $\quad 061$

062

063

when the 064

line 051 and they keep on

065

said, "yes",

066

067 Hermione (S) :

068

069 Teacher:

special]

070

not

071

072

073

074

075 Georgina (S) :

something it 076

very very like and

077

078

079 Teacher:

important to

080

just a little 081

082

083

lauder when 084

085 Whole class:
$(0.4)$

I need the tracking finger [going]

[ ${ }^{\circ}$ spes ] spes

${ }^{\circ}$ spe:cial ${ }^{\circ}$,

${ }^{\circ}$ special ${ }^{\circ}$

$(2.6)$

specially,

1.5)

Specially what do we think that sounds

that root word in [there?

[ $\{$ some students raise their hands \}]

$(0.1)$

[Ms. Tiggins told you about root words

root word that will be in specially?]

[\{students keep raising their hands\}]

$(0.4)$

yes. $=$

$=\{$ teacher pointing at Hermione $\}$ [other put their hands down

$(0.7)$

( (Students start to raise their hands teacher said, "there", in

raising their hands until the teacher

in line 059)

Special.

$(0.5)$

spe:cial: $(0.4)$ what is that [mean to be

[one student,

Georgina, raises his hand\}]

Georgina?=

$=\{$ the student's hand down $\}$

$(0.5)$

'It means to be something it means to be means to be something that you

$$
\text { important }{ }^{\circ}
$$

$(0.5)$

something that you lai:k a lo:t and is

you excellent $(0.1)$ next time let's try

$(0.5)$

bit more la: :ud.

what is that mean to be a little bit

we speakingi

Conviction 
Celtic: A Journal of Culture, English Language Teaching, Literature and Linguistics Vol. 7, No. 2, December 2020.

E-ISSN: 2621-9158 P-ISSN:2356-0401 http://ejournal.umm.ac.id/index.php/celtic/index

086 Teacher: conviction I can't 087 Tiggins is oold ( ) of 088

here

089

090

important to

091

that you

092

093

(0.2) specially

094

095

096

097 Teacher:

098

their hands \} ]

099

100 Teacher:

101

102

103

104 Omari (S) :

something special>

105

106 Teacher:

because it's

107

same

108

109

up \} ]

110 Some students:

111 Some other Students:

112

113 Teacher:

114

115 Student 2:

116

117 Teacher:

118

119

120 Teacher:

121

122

123

124 Teacher:

125

126 Teacher:

127

128 Teacher:
Thank you $\downarrow$ we need to speak with barely hear you now Ms.

hearing: (0.2) I can't hear you if I'm over okay, (0.4) she se: :d(0.7) tha: :t (0.3) to be special(0.4) mean you ( ) it was really

youl: $(0.6)$ and it was ve:ry it was something

like the whole lot(0.1) so something is specially $(0.7)$ specially mai: :d

mei:d (0.3) Ms. Tiggin specially meid

present for each of her students $\downarrow$

(0.9)

What do you think that[means?]

$[\{$ Students raise

(1.6)

[yes Omari]

[\{pointing at Omari\}] students' hands down $\}$

$(0.5)$

<I:: thi:nk it me: :ans you: make

$(0.5)$

I make something special for you : and

special do you think that I'm I give the

present (0.1) to [ everybody?

[ $\{$ students put their hands

[yes] ((calling out))

[No] ( (calling out))

$(0.3)$

ma : ybe $\downarrow$

$(0.8)$

YES YES MAYBE ((Student 2 calls out))

$(0.4)$

Who thinks no?=

$=\{$ students raise their hands $\}$

(2.3)

[Kaitrin [why not?] ]

[ Teacher pointing at Kaitrin $\}]$

[ other students' hands down\}]

(2.1)

Why do you think no?

$(2.4)$

$<$ something specially mai: $d \downarrow>$

$(0.5)$

will I give the same thing to everybodyc 
Sari, C.C. (2020). Conversation Analysis: Turn-Taking Mechanism and Power Relation in Classroom Setting. Celtic: A Journal of Culture, English Language Teaching, Literature, \& Linguistics, 7(2), 118-136.

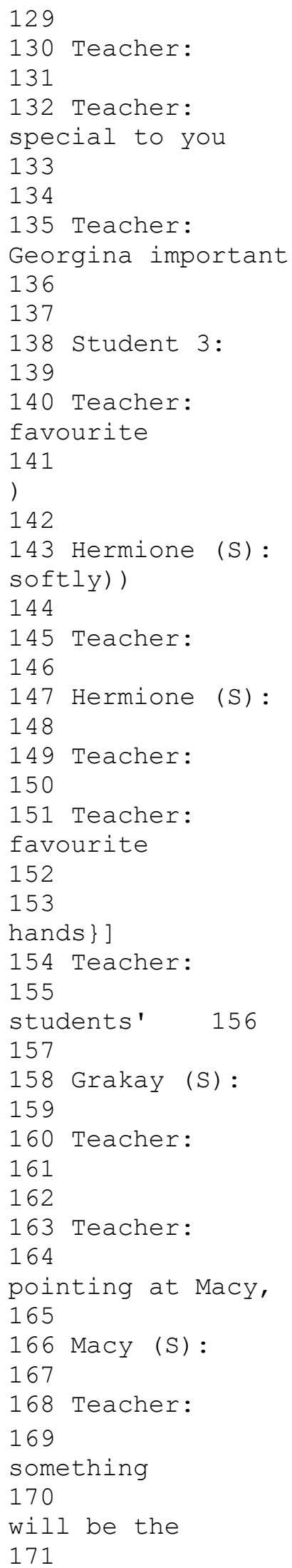

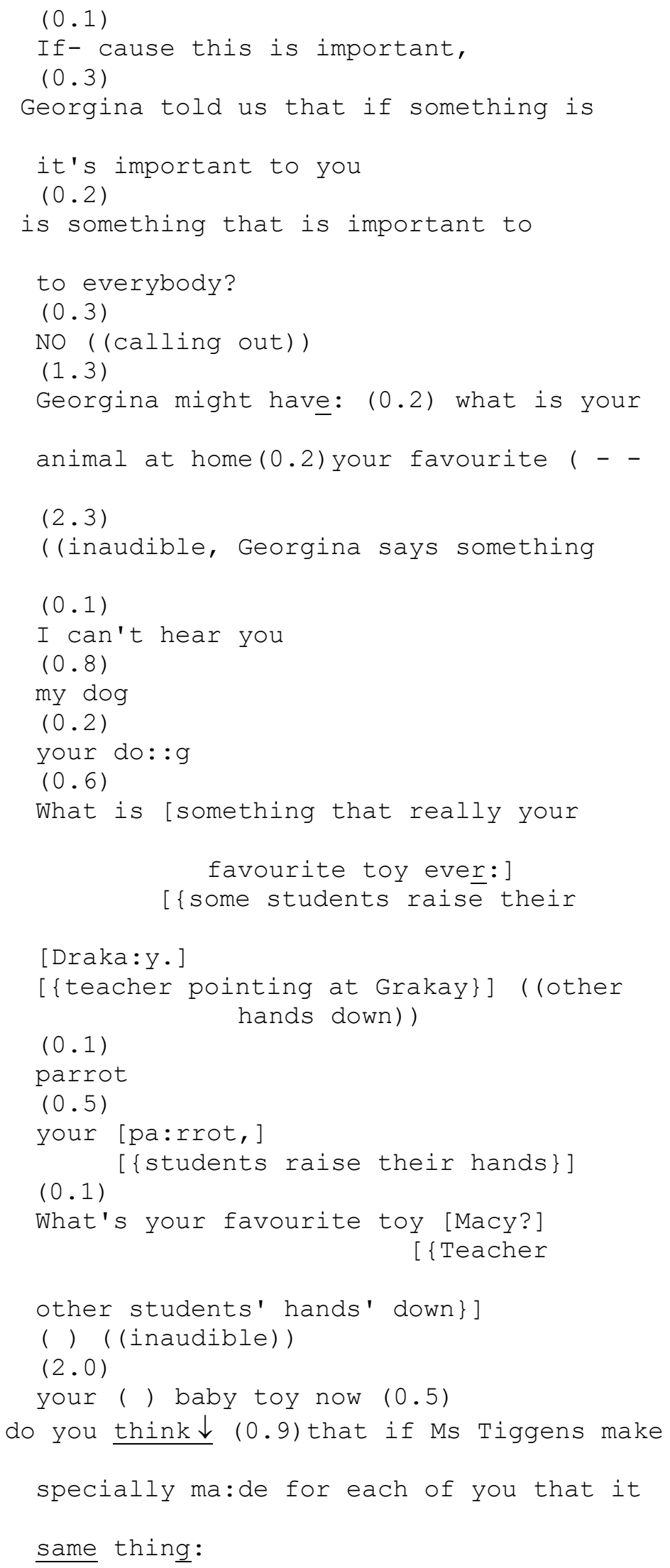


Celtic: A Journal of Culture, English Language Teaching, Literature and Linguistics Vol. 7, No. 2, December 2020.

E-ISSN: 2621-9158 P-ISSN:2356-0401 http://ejournal.umm.ac.id/index.php/celtic/index
172

173 Teacher:

they all be

174

175

176 Whole class

177

178 Teacher:

179

180 Teacher:

important to

181

182

183 Teacher:

184

185 Teacher:

186

you gu:ys $\downarrow$

187

188 Teacher:

Ms Tiggens's

189

Ms Tiggens 190

191

192 Teacher:

193

194 Teacher:

they're gonna be 195

class kids:

196

197 Teacher:

198

199

200 Student 4:

201

202 Teacher:

brownies our

203

specially made (0.5)

204

class or our

205

206

207 Whole class

208

209 Teacher:

210

211 Teacher:

212

213 Teacher:

214
(1.1)

will they all be different things or will

the same:

$(0.1)$

different

$(0.1)$

they're all different.

(0.1)

they're all different and they're all

you for different reason $\downarrow$

$(0.1)$

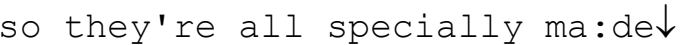

$(0.2)$

now, (0.7) let's think about this: (0.4)

If I specially made a special food for

$(0.1)$

I specially mai:d bro: :wnies (0.2) for

cla:ss(1.0)<specially made brownies for

(0.9)

cla: :ss.>

what do you think $\downarrow$

(1.4)

about these brownies do you think

the same brownies with Ms ( $\ldots \ldots$,

(1.5)

[whay: not?]

[ $\{$ teacher pointed at student 4\}]

$(0.5)$

<because some brownies are different $>$

$(0.1)$

some brownies are different and the

class has: $(0.5)$ because they are

means that important to who? Ms ( )

class?

$(0.3)$

our class ((calling out))

$(0.2)$

exa: :ctly,

$(0.1)$

let's look at the next word

$(0.6)$

struggle

(0.6) 
Sari, C.C. (2020). Conversation Analysis: Turn-Taking Mechanism and Power Relation in Classroom Setting. Celtic: A Journal of Culture, English Language Teaching, Literature, \& Linguistics, 7(2), 118-136.

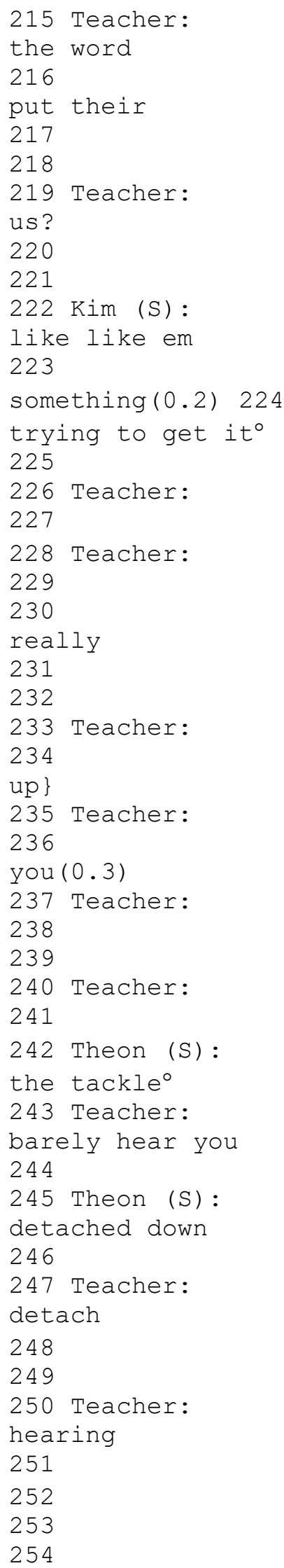

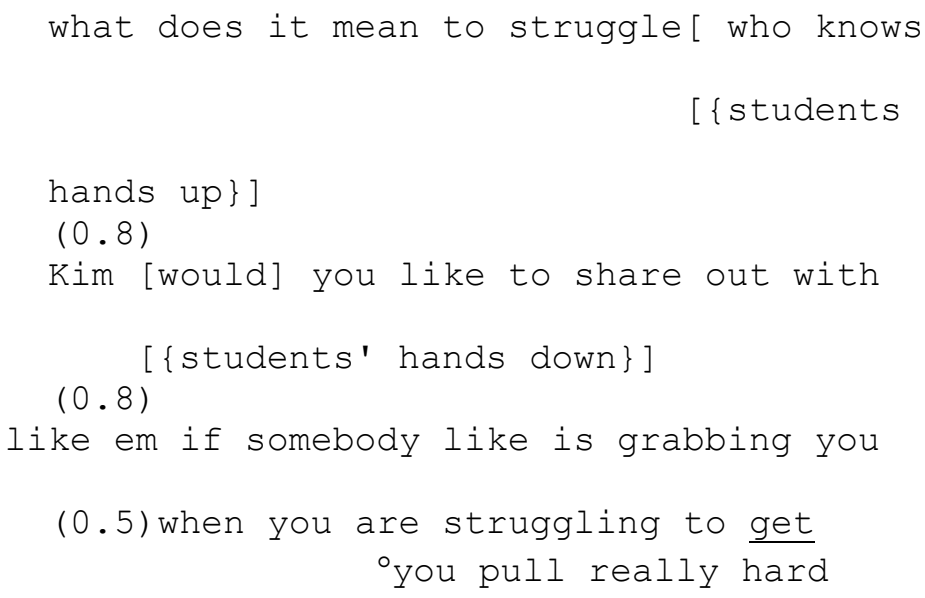


Celtic: A Journal of Culture, English Language Teaching, Literature and Linguistics Vol. 7, No. 2, December 2020.

E-ISSN: 2621-9158 P-ISSN:2356-0401 http://ejournal.umm.ac.id/index.php/celtic/index

255
256

Angelica\} ] 257

down) \}

258

259 Angelica (S) :

Ma: : th $>(0.1)<$ somebody

260

261

262 Teacher:

interesting

263

class I like

264

265

266 Whole class

267

268 Teacher:

269

270 Teacher:

like you're

271

body right?

272

273 some students:

274

275 Teacher:

can Math

276

277

278 Whole class:

279 Teacher:

280

281 Teacher:

Ma: th $\downarrow$

282

283 Teacher:

you going

284

you got it

285

286 Teacher:

287

288 Angelica (S) :

something

289

answer $(0.1)$ you can get 290

291 Teacher:

louder with

292

here need to what do you think [Angelica?]

[ $\{$ Teacher pointed at

( (other students' hands

$(0.1)$

$<$ like if you struggling on your

can help you>

$(0.3)$

what would that me:an: that's that's an

one in fact I lo:ve how she's thinking

how she's thinking $\downarrow$

$(0.3)$

we think is great

$(0.1)$

It is great you know what $\uparrow$

$(0.4)$

because they say that you're struggling

movin (0.2) somebody holding on to your

$(0.1)$

yes

(0.1)

she said that you're strugling with Math

hold on to your body?

$(0.1)$

no

Math cannot hold on to your body $\downarrow$

$(0.2)$

but how could you be struggling in

$(0.6)$

what does it mean Angelica $\uparrow$ I like where

with this I think it's right he:re I think

$(0.1)$

what does it mean to struggle in Math?

$(0.5)$

$<^{\circ}$ it means like(0.1) if you stuck on

(0.1) you don't know what's the

help from somebody ${ }^{\circ}>$

would you mind saying that a little bit

conviction first because everybody in 
Sari, C.C. (2020). Conversation Analysis: Turn-Taking Mechanism and Power Relation in Classroom Setting. Celtic: A Journal of Culture, English Language Teaching, Literature, \& Linguistics, 7(2), 118-136.

293

lauder with

294

295

296 Angelica (S) :

and you

297

to get some

298

399

300 Teacher:

$\mathrm{Ma}:$ : th

301

the a:nswer 302

from somebody(0.4) so you

private tutoring session

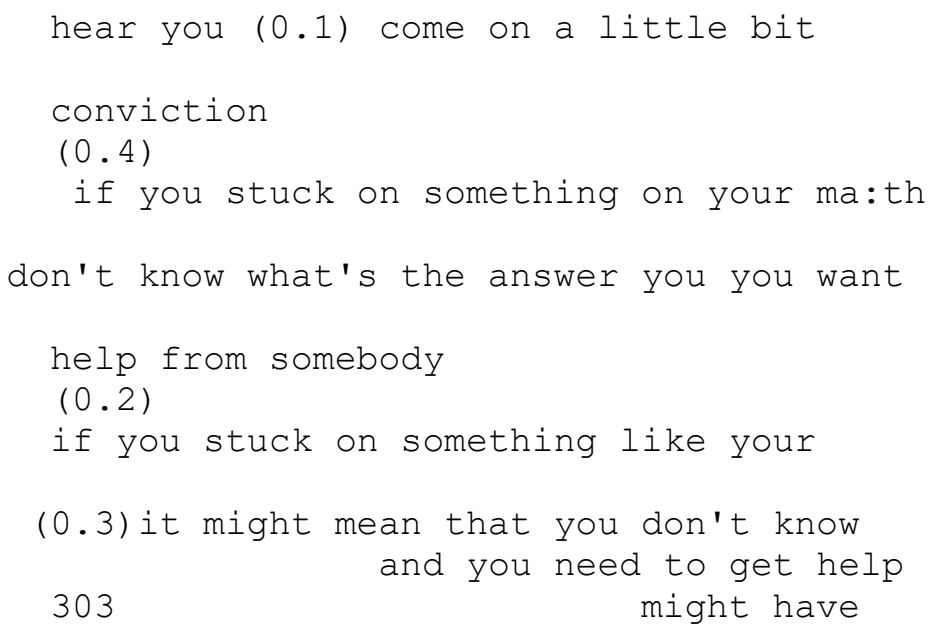

